\title{
On Gospel Guidelines and Critical Conceptual Frameworks
}

\author{
by Larry Jorgensen
}

\section{The Churches' Communication}

When churches discuss communication, they are usually light on theory and move directly into their own preoccupations. That is normal for international organizations. When Unesco's International Commission for the Study of Communication reported in 1980,' for example, it made no pretense with respect to theory. All it indicated were possible correlations between research and its own interests.

When churches discuss communication, and therefore their own preoccupations, they speak of communicating Christ, communicating the gospel, communicating themselves. Of reaching out. That missionary concern is shared with other organizations. As was once observed: „'winning people' seems to be of as paramount importance in human kind's history ...' everyone is basically a missionary'“.'

On the one hand, it would be unfair to single the churches out for concentrating too much on use of the media. They are beset by the same human weaknesses as other institutions. But on the other hand, they should be held accountable for a consistent use that runs counter to the standards they purport to preach. John Bluck records a Christian expression of the use motif: ,an increasing number of Christians (especially those who have grown up with television as part of the living room furniture) see the media as a theatre for God's action in the world"; he summarizes that mindset "God made it - let's use it". ${ }^{3}$ Virginia Stem Owens sees this as getting out of hand in the United States, where there are advertising campaigns for salvation, poor imitations of other people's products, and a Christian establishment „overjoyed and entirely uncritical of its novel opportunities to become a media manipulator itself". ${ }^{4}$ Cees Hamelink judges that „very often church journalists accept rather uncritically the dominant techniques, standards and models of disseminating information, thus becoming part of an unjust structure that supports and legitimizes gross inequalities in the world". 5

There are various possibilities for dealing with the discrepancies between (sometimes) worthy intentions and (sometimes) ignoble results. A first possibilit. would be to move from church use of the media to wholehearted cooperation in the secularized media. ${ }^{6}$ The churches would no longer throw a cloak of sanctity over bits and pieces of the media, immediately Christianizing them. They would see all of the media as part of a world that God has accepted, as mediately Christianized realities. But this flies in the face of Christians intent on "winning people“. And it might also be seen as sacrificing (sometimes) noble intentions for implication in (sometimes) ignoble results.

Dr. Larry Jorgensen studierte Kommunikation und Theologie in Löwen, wo er mit einer Arbeit über Pressefreiheit und das Recht auf Information promovierte. Er arbeitet vorübergehend an einem. Forschungsauftrag beim Weltrat der Kirchen in Genf. 
A second possibility' would be to accept the fact that the churches want to "win people“ as much or more than other organizations. While calling for a deliberate comparison between what they are doing and what is actually said in the New Testament. Those who defend the electronic preachers see them as following in a literal way the command to go forth and teach all nations. But those who seek guidelines for a truly Christian communication sometimes doubt whet her the electronic church squares with the gospels. The search for such guidelincs is considered in the following section.

A third possibility ist suggested by Hamelink.? He notes "the churches' extensive participation in communication media that are controlled by corporate industry". He then claims that with no critical conceptual framework of their own, they will adopt a public communication shaped by industrial interests. There and elsewhere ${ }^{8}$ he proposes some hard thinking by the churches before they board the media. This possibility differs from the previous one in that it necessitates more sophistication about communication itself and more reflection prior to beginning media work. An obvious problem with Hamelink's suggestion is the need for theory, of which international groups like the churches have been seen to be impatient. But the proposal has its merits and demands at least the attention given it below.

\section{Gospel Guidelines}

This section summarizes two attempts to articulate these. The first is made by Anne van der Meiden in her doctoral thesis on ethics, propaganda and apostolate. ${ }^{9}$ The second is made by the World Council of Churches (WCC). ${ }^{10}$ Their attention to gospel standards - in van der Meiden's terminology - or to gospel criteria - in the WCC's - does not exclude theory. But the elaboration of such guidelines is their main focus and this presentation limits itself to that.

\section{Van der Meiden's thesis on ethics, propaganda and apostolate}

Part of this work concentrates on Jacques Ellul's rejection of evangelism via the mass media." That section of the Ellul corpus brings together two parts of the author's career: Ellul as "quintessential Protestant"12 and Ellul as expert on propaganda. ${ }^{13}$

As van der Meiden sums it up: Ellul rejects evangelism through the media on gospel grounds. The media address a "mass“, whereas the Christian God addresses the individual person. They are "techniques" of which the Holy Spirit has no need. They play on conditioned reflexes that have no rapport with faith. And they will fail because of what the „quintessential Protestant" sees as the rupture between nature and grace.

But van der Meiden finds some middle ground between uncritical use of the media and Ellul's outright rejection. Van der Meiden takes the mass media critically but not negatively; they represent human activity and therefore human ambiguity. Even though there is "massification", there might also be some good done. He is willing to accept evangelization through the media as long as that activity is true to standards distilled from the gospel: authenticity, freedom and responsibility. True, that is, to the standards one purports to preach.

Media manipulation and sales campaigns for salvation do not measure up to the standards of authenticity, freedom and responsibility. But other media work might. For example, to contact the socalled para-church: „... research does reveal that there are numbers of people whose religious concerns are greater than their church attendance would indicate, so there would seem to be at least some opportunity with this group“..14 
As one of the study resources puts it: „criteria are much needed, but need to be developed with great care. Like ice cubes, they can melt in your hand if clutched too tightly". ${ }^{15}$

Guidelines for credible Christian communication start with the whom (Jesus Christ) or the what (the gospels) one hopes to communicate. It has been asserted that „substance rather than technique is our starting point, though it quickly leads to choices about the media ..."16 Elsewhere it has been said that ,... to take seriously whom we communicate does provide some sharp answers to how ... we are to communicate as Christians". ${ }^{17}$ Identifying the whom and the what is the main thing; other criteria like respect for two-way communication flow from that.

In some ways these criteria compete for attention with the central canon of Western media orthodoxy: neutrality, reporting and not supporting. Or how Western media determine what is or is not newsworthy: timeliness, prominence, proximity and the like. The gospel criteria keep professionalism from becoming an end in itself.

As did van der Meiden's gospel standards, the WCC criteria point to a middle ground between uncritical use and outright rejection. While the electronic preachers pay a lot of lip service to the who and the what, they seem to stay on the level of how in their professionalism. But there are other instances of media work where the who and the what actually do determine the how. ${ }^{18}$

\section{Doubts About Their Adequacy}

There are some who find such guidelines insufficient. They would note, for example, that reflection on the gospels has given rise to dozens of theological schools. And that scripture has been used to argue both sides of many issues: pacifism v. violent revolution, unilateral disarmament $v$. nuclear deterrence, and so on. Taking communicr ..on guidelines from the gospels would certainly allow lots of latitude. Moreover, the gospe; guidelines seem to offer no critique on the injustices of the information and communication order. They appeal to the consciences of would-be media manipulators, which might not be enough. ${ }^{19}$ These are points well taken. They cannot be rebutted to everyone's satisfaction. But they can get a response.

\section{A Chance With The Churches}

The positive side of taking guidelines from the gospels is that it is an activity in which the churches have some competency. This is already a major selling point. The churches's dabbling in sociology, economics and political science has compromised some of the worth while things they have had to say on complex issues like development. ${ }^{20}$ Their dabbling in communication theory would probably allow similar resistance.

Since the guidelines come from the gospels, they have a chance of being heard and understood by those who make the churches' communication options. If the guidelines are accepted, they might not be uniformly applied. But they might encourage a more critical use of the media. That goal is modest; as such it stands a chance of being reached.

\section{Churches as Leaders in Communication}

Those who look for critiques of unjust systems sometimes overlook the value of setting a good example. Years ago, Emile Gabel called on the churches to set a good example in 
communication, to be leaders and not followers. ${ }^{21}$ The gospel guidelines might help them to lead, to stop imitating others.

Besides that, any critique by the churches of media systems will lack credibility so long as they are mesmerized by them. Reference to gospel-based standards or criteria in their own communication policies would render them more credible should they choose to speak to global communication problems. A parallel case is the WCC's withdrawal of all its funds from banks doing business with South Africa; that made the WCC more credible to some when it spoke about apartheid.

In a way this is the inverse of Hamelink's proposal, where a critique of media systems would precede use of the media. In this approach, the churches' own ethical choices would serve as the backdrop for what they have to say about global problems.

\section{Summary and Transition}

This section has shown one possibility of dealing with a discrepancy in the churches' communication: that between what they practice and what they preach. It sketched two proposals for gospel guidelines that would make the practice fall in line with the preaching. It foresaw criticisms and tried to respond to two likely ones.

The following section will treat another possibility of dealing with the discrepancy: the elaboration of eritical conceptual frameworks that are longer on theory and social critique. The gospel criteria were seen to be vulnerable because they are short on those elements. While critical conceptual frameworks escape that, they too have their difficulties.

\section{Critical Conceprual Frameworks}

The problem is not finding a critical conceptual framework; it is getting people to agree to one. Communication is the subject of at least fifty research disciplines, all of which have their own interests - interpersonal or mass communication. long-term or short-term effects, and so on - and all of which operate under a variety of administrative and financial pressure. Although the different disciplines sometimes influence each other, there is no universal communication theory. What there are, are numerous definitions and schemas, and salespeople for those.

Writing about the philosophical approaches to communication, Paul Soukup concludes that "one's choice of communicative situation largely determines which philosophical tradition will be most helpful". ${ }^{22} \mathrm{He}$ observes for instance that mass media situations would be better studied through phenomenology, semiotics or critical theory. And that interpersonal dialogue should be approached from personalist philosophy or speech act theory.

Soukup's suggestion seems reasonable enough, especially since - as he observes - the various philosophies of communication have common sources or have at least cross-pollenated each other. But in passing it might be asked how much the choice of communicative situation really influences the choice of philosophical tradition. Salespeople for critical theory apply it to every communicative situation, mass and/or interpersonal. Salespeople for personalist philosophy do the same.

Critical theory is of importance here because some of its salespeople are trying to get the churches to buy it. When Hamelink calls for a critical conceptual framework, he probably has critical theory in mind. His own approach to public communication is certainly „... from a dialectic materialistic (and ideology-critical) analysis of the concrete social parameters (and ideological limitations) which essentially determines ... structure and function". ${ }^{23}$ 
Which is fine for an individual's option. But is it reasonable to expect church groups to take that option too?

First of all, buying critical theory is taking sides on a discussion about ideology and popular culture that has been going on for a half century; one can expect criticism from other salespeople. ${ }^{24}$ Second, buying critical theory would be acceptable to some political messianisms present in the churches but not to others. Third, buying critical theory would probably be „explained“ in ways that would make agreement even less likely. ${ }^{25}$

Again, this is not to condemn critical theory as an individual's option. Discovering critical theory must be (something) like what Thomas Aquinas experienced when he discovered Aristotle. It is to suggest the difficulties the churches will have in accepting it as a critical conceptual framework.

For a variety of reasons, personalist philosophy meets less resistance. it is already better known to the churches, partly because it was introduced in a communicative way not only by Martin Buber in Ich und Du (1923), but also by Franz Rosenzweig in Stern der Erlösung (1921) and Gabriel Marcel in his Journal métaphysique (1920s). Their thought, and discussion of dialogue, has so influenced the churches that "dialogue" has almost become a cliché for them.

Choosing personalist philosophy avoids other risks run by choosing critical theory. It does not stand on one side of a research schism, it does not find favour with one political messianism above others, and its familiarity means that „explanations“ are not as much of a problem.

Two trends in personalism seem fruitful and should be summarized here.

\section{Buber's I and Thou 26}

As people know - either through osmosis or personal study - the 1-Thou relationship is one where both parties are subjects; neither is treated as an object. They are present to one another and respectful of one another. Neither is simply a sender or a receiver; both fill both roles. Contrasted to that is the I-it relationship where the parties are not full partners, where there are subject and object, an $\mathbf{l}$ and an it.

Scholars now dispute Buber's intention in distinguishing an I-Thou and an l-it. Rika Horwitz claims he was trying to ground religious belief. ${ }^{27}$ This might explain the sharpness of the distinction, which was first criticized by Rosenzweig when lch und $D u$ was in galley proofs. ${ }^{28}$

But others see Buber's distinction in light of Tönnies' equally sharp line between Gemeinschaft, a community (of I-Thou relationships), and Gesellschaft, an association (of Iit relationships). Thus, Buber emerges as a social philosopher ${ }^{29} \mathrm{Horwith}$ says that archives opened to scholars after Buber's death in 1965 dismantle the image of Buber as social philosopher. But some authors who have had access to those archives still present him as such. ${ }^{30}$

Buber studies have become a specialization in their own right. Quite a lot has been said about the I-Thou/l-it distinction and what the philosopher intended with it. But there is room here to recall only one discussion, that which took place between Harvey Cox and Martin Friedman on the possibility of middle ground between the I-Thou and the I-it.

Cox began the discussion in The Secular City, ${ }^{31}$ where he noted the desire of urban dwellers to separate their private lives from their public lives. Their private relationships might be IThou; their public ones are not l-Thou although they still can be human. This phenomenon led Cox to posit an I-you relationship: a relationship with both the humanity of the I-Thou 
and the anonymity of the l-it. l-you relationships were casual and everyday; they were the style of the city.

Friedman took issue with this, claiming that Cox had confused intimacy with courtesy. ${ }^{32}$ Friedman's reading of Buber led him to see the phenomenon described by Cox in another way: the I-Thou ,.... permeates the world of I-it, transforming it. Hence no I-you relationship is needed in addition to the I-Thou and the I-it ...". And Friedman got Cox to admit that before two hundred ministers at Union Theological Seminary, New York, in 1967.

The Cox-Friedman debate might look a little esoteric, or seem to be of significance only to interpersonal communication. But the application to mass communication is easily made. Some years ago, Albert van den Heuvel observed the difficulty of making I-Thou relationships the goal of all human interaction. ${ }^{33}$ The entire project seemed class-bound and anti-democratic to him, since traditionally "the masses had neither the time or the opportunity to communicate“. Van den Heuvel, following Cox, remarks that ,in our urban mass-societies communication is normally casual but therefore not less real". He infers that mass communication, while definitely not I-Thou communication, can be I-you communication.

The Cox-Friedman debate has not made nonsense of van den Heuvel's remarks. The former offers a means of rephrasing the latter. Mass communication is not l-Thou; it is generally speaking l-it. But there can be instances where the l-Thou penetrates the l-it, transforming it.

Giving away one of the conclusions to this paper, gospel guidelines pertain to I-Thou communication but are applied to an l-it world. As such, they could be seen as the penetration of the I-Thou into the l-it, and the possibility of changing it. Connection between gospel guidelines and this critical conceptual framework are, therefore, feasible.

\section{The Personalist Criterion}

Personalist approaches have in common a respect for the human person. In Buber's philosophy, that respect was seen in terms of an I-Thou, dialogical relationship. This section now considers another articulation of that respect: the elaboration of a personalist criterion. Briefly, this is the assertion that human activity should be appraised according to the integral and adequate consideration it gives the person. ${ }^{34}$ This sort of personalism has been cited as one of the influences on the pastoral constitution of the Second Vatican Council, Gaudium et Spes (1965). ${ }^{35}$

Integral and adequate consideration includes deference to the person's social dimension: coexistence, co-operation, and co-participation. So far, this is quite similar to Buber with his emphasis on dialogue and hence community. But this style is better equipped to deal with some messy areas that demand harder thinking and recognition of the ambiguity of the human situation. Integral and adequate consideration of the person, for example, will take into account both the person's originality and his or her social context. Often the extent to which the former can be respected is severely limited by the latter. A marginal case would be when education is short changed by a government because the funds are needes to supply emergency food, clothing and shelter. That choice, like all choices made in the real world, is both for something and against something else.

The personalist criterion is explained at some length in various places. The only thing that can be done in this paper is to apply the above summary to communication. The applications are to be found in two areas.

First, when the personalist criterion includes the social dimension - co-existence, cooperation, and co-participation - it implicitly rccognizes the role of communication. Words 
with the prefix „co-" are close etymologically to words with the prefix „com-“, like communication; they indicate joint action. One-sided action, manipulation including media manipulation, could only be justified by proportionate reasons. Those acting one-sidedly usually have a reason, but it's not often good enough.

Second, the personalist criterion also provides a way into discussions about mass communication. The Western heritage of natural law contributes to a view of the individual in isolation, with isolated freedoms and rights, duties and responsibilities. That means that judgments are often made on human activity apart from the whole action and the whole context - „in the sense that what is done (actus externus) is denounced as in itself and intrinsically immoral". ${ }^{36}$ Natural law - passed through the enlightenment and the bourgeois revolutions - is the source of the concepts freedom of the press and right to information. The freedom and the right are often formulated with worthy objectives, but they are foreign to most places. ${ }^{37}$ And often they are summoned in disregard for the social context. ${ }^{38}$ The difference here is that the personalist looks at the whole action and the whole context; free press advocates look at an „actus externus“ and jump at the chance to pronounce on its immorality.

A lot more could be said on either of these applications. ${ }^{39}$ Hopefully this will suffice as a summary, and as a hint of another of this paper's conclusions. Theologically, Jesus Christ reveals what is meant by the integral and adequate consideration of the person; scripture shows that to be respect for authenticity, freedom and responsibility. Connections between gospel guidelines and this critical conceptual framework, then, are also possible.

\section{Doubts about their Adequacy}

This of course will sound naive to some. In fact Buber's personalism was seen during his own life time as an excuse for withdrawing into a private garden. Which was never a comment on Buber himself, only on those who abused his writings. As to the personalist criterion, people have been articulating that for a while and it has found its way into one of the major church documents of this century. But to what avail is that if things are not changed for the better? Why, then, accept either style of personalism as a critical conceptual framework for dealing with mass communication?

All this fits into larger discussions. How does one change things for the better? How do churches that are frequently in a minority position contribute to the search for democratic structures? Admittedly, those discussions often take place in private gardens between bourgeois clerics and lawnchair marxists who have no intention of getting their hands dirty. But perhaps it is not too romantic to assume that those discussions go on in some difficult situations, where the clerics are not bourgeois, the marxism is not affected but the hands are dirty.

Few would feel the loss of discussions in private gardens. Hopefully there are ones going on in the fields. All this paper can do is to express that hope. And to make two responses to those who find the personalist perspective too cozy.

\section{Building Awareness}

One of the most frustrating things about discussing the mass media is getting people to realize that there is a problem. ${ }^{41}$ North Americans have been passing off scornful remarks about television for years: "the vast wasteland“, „chewing gum for the eyes", and „a medium in the sense that it is neither rare nor well done“. But it has recently been said that "to get a North American to think about television is like getting a fish to think about water". Even people who are not swimming in mass media have difficulty thinking about them; often they are seen as the panacea. ${ }^{41}$ 
Awareness is a modest aim; it is, however, a worthy one. Beginning with either style of personalism, which already has a foot in the door, offers some chance of awareness. That is already something of a success. Other ways into the mass media, which are not as familiar, usually amount to preaching to the already converted. ${ }^{42}$

There is not necessarily a rupture between theory and practice; there can be bridges between media awareness and action. Fallible approximations of what human communication should be serve, in a way, as incentives to achieve it on both the interpersonal and mass levels. As Cox once said; "the full realization of total human communication will probably never come. Still, even in this 'fallen age', we can occasionally experience it, and once we do we can never settle for pseudo-communication again". ${ }^{43}$

\section{Sharpening Personalism's Political Edge}

Those who find Buber's personalism helpless against unjust structures have recently been invited, by Venecio De Lima and Clifford Christians, to introduce that dialogical thinker to another: Paolo Freire. ${ }^{44}$ They begin by observing that ,... the non-directive, humane, communitarian character of (Buber's) theory give dialogue a romantic and naive appearance, especially to media scholars concerned that 'one-wayness' is just a euphemism for concentrations of power". Freire is much more direct. He introduces the concepts of „speaking the true word" and "naming the world“, which take one more quickly from political awareness to the quest for human liberation.

The shift from Buber to Freire, from non-directive to directive, gives dialogue a political edge. No style of personalism has to remain non-directive and therefore politically impotent.

\section{Summary and Transition}

This, then is another possibility for dealing with the discrepancy between the churches' communication practice and the content of their preaching: adopting a critical conceptual framework with which present communication systems can be examined; and using the results in determining how to proceed with media work.

Different critical conceptual frameworks have been introduced here. Critical theory was lauded but found unlikely as an option for the churches. Two styles of personalism were presented at greater length; they looked more likely, and some of their selling points were noted.

But again, this paper presents the adoption of a critical conceptual framework as a possibility among other possibilities. In addition to the problems mentioned in this section, there are questions that such an approach would leave unanswered. For one thing, what happens once a critical conceptual framework is accepted and cxisting media systems are found wanting? Would the churches make strange bedfellows in order to achieve higher purposes? Would they refuse to participate, and in a sense abandon the conscientious Christians who work in those media systems? Would they do more on their own, thus combining awareness of the established media with support of alternative ones'? Or what?

Clearly, the adoption of a critical conceptual framework cannot be the end of the difficulties. This paper makes no pretense of knowing the answers to the questions that would be raised and simply moves on to its own conclusions. 


\section{Three Conclusions}

The previous section gave away two of the three conclusions. The first is the obvious intersection between the gospel guidelines and the personalist philosophy of Buber. The point of intersection has already been identified. It is the ground between the I-Thou and the I-it. Where the I-Thou penetrates the I-it - to use Buber's terms - or where the guidelines serve as criteria for mass communication - to use the terms of those who have articulated them.

The second ist the way the gospel guidelines and the personalist criterion come together: in Christ as the inspiration for such guidelines and the model for what it means to respect the human person.

An interesting area for further investigation might be the possibility of refining those practical principles through the refinement of the personalist philosophy.

Perhaps this already dares too much. The $t$ hird conclusion is more humble. It returns to the necessity of awareness; almost any way of discussing the media that improves awareness has its value. Without that awareness, the churches can make no bold pronouncements: „a slower, self-critical, awareness-building process is required, defining more clearly what is at stake, building up from the experience of local churches, rather than down from the expertise of media professionals". ${ }^{45}$

\section{Foot Notes:}

I Many Voices, One World. Communication and Society, Today and Tomorrow. Report by the International Commission for the Study of Communication Problems, Paris, 1980.

2 ENIS. Towards an Ecumencial Network of Information Systems (Lutheran World Federation), Geneva, 1974, p. 13.

3 Beyond Neutrality. A Christian Critique of the Media (Risk Book 3), Geneva 1978, p. 3.

4 The Total Image. Or Selling Jesus in the Modern Age, Grand Rapids, 1980, pp. 26ff.

5 Towards a New International Information Order (CCIA/WCC Background Information 1978/7), Geneva, 1978, p. 20.

6 Based on a reading of authors like H. Cox. The Secular City. Secularization and Urbanization in Theological Perspective, London, 1965; and J.-B. Met7., Theology of the World (translation), London, 1965.

7 The Corporate Village. The Role of Transnational Corporations in International Communication (IDOC Europe Dossier 4), Rome, 1977, p. 211.

8 Perspectives for Public Communication. A Study of the Churches' Participation in Public Communication. Baarn, 1975.

9 Mensen winnen. Een verkenning van de relatie tussen ethiek, propaganda en apostolaat (Rijksuniversiteit Utrecht), Utrecht, 1972.

10 Especially the study resources: Communicating with Conviction, in Issues. Discussion Papers on Issues Arising out of the Life and Work of the World Council of Churches in Preparation for Its Sixth Assembly. Vancouver, Canada. July 24 to August 10. 1983. Geneva, 1982, paper no. 8; and Credible Christian Communication. A Study Resource for Local Churches, Geneva, 1983.

$11 \mathrm{Cf}$. Ellul's publications: The Obstacles to Communication Arising from Propaganda Habits, in The Student World, 52(1959) 401-410; Evangélisation et propagande, in Revue de lévangélisation. n.s. $15(1959)$ 146-162.

12 M.E. Marty, Creative Misuses of Jacques Ellul, in C.G. Christians and J.M. Van Hook (eds.), Jacques Ellul. Interpretive Essays, Urbana, 1981, 3-13, p. 4.

13 For example: Propagandes, Paris, 1962; Histoire de la propagande, (Que sais-je? 1271), Paris, 1967. 
14 The Churches and New Communications Technologies - Progress Report (Lutheran World Federation), Geneva, 1982, p. 7.

15 Credible Christian Communication ... (see note 10 above), p. 13.

16 Communicating with Conviction ... (see note 10 above), p. 2.

17 Credible Christian Communication ... (see note 10 above), p. 7.

18 Some examples are given by Kathy Lowe, Opening Eyes and Ears. People and Churches That Do Communicate, Geneva, 1983.

19 Cf. G. Deussen, Ethik der Massenkommunikation bei Papst Paul VI (Abhandlungen, Sozialethik 5), Munich, 1973, p. 280; also B. Häring. Free and Faithful in Christ. Moral Theology for Priests and Laity, v. 2, Slough, 1979, p. 166.

20 Questions about the WCC's competence have been raised by Ellul. The Ethics of Freedom, Grand Rapids, 1976, p. 387; questions about Roman Catholic competence have been reported by P. Fransen, The Exercise of Authority Today. Its Concrete Forms, in Louvain Studies, 10(1982) 3-25, p. 22.

21 L'Enjeu des média, Paris, 1971.

22 Philosophical Approaches to the Study of Communication, in Media Development, 30(1983) no. 1, pp. 3-6.

23 Perspectives ... (see note 8 above), p. 101.

24 Some critical points are raised by J. Carey, Mass Communications Research and Cultural Studies. An American View, in J. Curran, M. Gurevitch and Janet Woollacott (eds.), Mass Communication and Society, London, 1977, 409-427.

$25 \mathrm{Cf}$. van der Meiden, Alleen van horen zeggen. Bouwstenen voor een communicatieve theologie, Baarn, 1980, pp. 93-94. He reports a popular discussion about the recording of a Mendelssohn concerto: capitalists are behind it; if they weren't, there would be no access to Mendelssohn; and so on.

26 This paper will render Ich und $\mathrm{Du}$, ,I and Thou“, thus following earlier practice and not that of some later translators.

27 Buber's Way to „1 and Thou". An Historical Analysis and the First Publication of Martin Buber's Lectures „Religion als Gegenwart“ (Phronesis 7), Heidelberg, 1978.

28 M. Buber, Briefwechsel aus sieben Jahrzehnten. (Grete Schaeder ed.), vol. 2, Heidelberg, 1973, pp. 124-128.

29 As he does for P. Tillich, Thcology of Culture, New York, 1959.

30 For example: M. Friedman, Martin Buber's Life and Work. The Early Years 1878-1923. New York. 1981; and T. Dreyfus, Martin Buber (Témoins spirituels d’aujourd’hui), Paris, 1981.

31 Op. cit. (see note 6 above), pp. 40-46.

32 Friedman, op. cit. (see note 30 above), pp. 34I-342, 431.

33 A Meditation about Theology, Communication and the Mass Media, in Teaching All Nations, 6(1969) 353-372, p. 359.

34 Cf. L. Janssens, Norms and Priorities in a Love Ethics, in Louvain Studies 5(1977) 207-238; and idem, Artificial Insemination. Ethical Considerations, in Louvain Studies, 8(1980) 3-29.

35 According to: D. R. Campion, The Church Today. A Response, in W. M. Abbott (ed.), The Documents of Vatican 1I, New York, 1966, 183-198; and Janssens, Norms ... (see note 34 above), p. 237.

36 Janssens, Norms ... (see note 34 above), p. 237.

37 Observed for example in Human Rights and Christian Responsibility, in The Churches in International Affairs. Reports 1970-1973 (World Council of Churches), Geneva, 1974, 111-117.

38 Freedom of the press has been used as justification by press monopolies in Canada (Reuter Wire Service, 6 July 1983) and elsewhere.

$39 \mathrm{Cf}$. L. Jorgenson, Freedom of the Press and Rigbt to Information (Katholieke Universiteit Leuven), Louvain, 1981, pp. 301-316.

40 On media awareness: Judith M. Buddenbaum, Media Awareness/Education Programs. Analysis of an LWF Survey (LWF Documentation 9), Geneva, 1981.

41 This was observed in a recent WCC survey: B. Bennet, P. Flemington and C. Ceccon, From Silence the Soul Will Speak. Ways and Means of Communication in the Diocese of Maseno, South Kenya. An Evaluation and Proposal for People-based Communication, Geneva, 1981. Summarized in: J. Bluck, Where Media Are not the Message, in One World, (1980), no. 75, pp. 18-20. 
42 As is sometimes the case when the NWICO debate is chosen as the way in. Cf. Reactions of Christians in General to Unesco's Course of Action on the New World Information and Communication Order (NWICO) and the MacBride Report in Particular (International Catholic Centre for Unesco), Paris, 1981. There it is shown that the rank and file don't know about NWICO.

43 Seduction of the Spirit. The Use and Misuse of People's Religion, New York, 1973, p. 316.

44 Paolo Freire. The Political Dimension of Dialogic Communication, in Communication, 4(1979) 133-155. Freire's Pedagogy of the Oppressed, New York, 1970 is cited by them as the most extensive elaboration of his concept of dialogue.

45 Credible Christian Communication ... (see note 10 above), p. 5.

\section{ZUSAMMENFASSUNG}

Wenn die Kirchen über Kommunikation sprechen, kümmern sie sich meist wenig um Theorie und gehen sofort zu ihrem Anliegen über, wie es für internationale Organisationen üblich ist. Die Kirchen sprechen von der Kommunikation Christi, der Kommunikation des Evangeliums, sie wollen Menschen gewinnen. Man kann ihnen das nicht vorwerfen, aber eigent lich müßten sie sich dessen bewußt sein, daß dies genau dem entgegenläuft, was sic predigen. Sie übernehmen zu leicht unkritisch die vorherrschenden Kommunikationstechniken und werden so leicht auch Teil einer ungerechten Struktur (Hamelink). Es gibt verschiedene Wege, mit berechtigten Zielen und oft unerwarteten Ergebnissen fertig zu werden. Der erste Weg wäre, sich weg vom rein kirchlichen Gebrauch der Medien voll der Kooperation in den weltlichen Medien auszuliefern. Die Medien werden hier einfach als Teil einer von Gott gewollten Welt gesehen, aber diese Haltung entspricht eigentlich nicht dem Ziel des Menschen, diese Welt zu gewinnen. Der zweite Weg wäre, das Anliegen der Kirche, Menschen zu gewinnen, gleichzusetzen mit gleichen Anliegen ähnlicher Organisationen. Dies wäre der Weg der elektronischen Kirche, von dem manche bezweifeln, ob er der Weg der Evangelien ist. Hier wird man wohl Richtlinien erarbeiten müssen, was teilweise versucht wird.

Ein dritter Weg, wie er von Hamelink vorgeschlagen wird, wäre, ein eigenes kritisches Rahmenkonzept zu entwickeln, bevor die Medien gebraucht werden. Ein solches Konzept verlangt ein tieferes Nachdenken über Kommunikation, und es erfordert eine Theorie, die wohl noch nicht vorhanden ist. Unter dem Stichwort Evangelische Richt linien gibt es zwei Versuche, jenen von Anne van der Meiden in seiner Dissertation über Ethik, Propaganda und A postolat und dann einen des Weltrates der Kirchen, der bei biblischen Kriterien Theorie nicht ausschließt.

Ein Teil der Studie van der Meidens geht aus von Jacques Ellul's Ablchnung von Evangelisation durch die Massenmedien, die cr auf das Evangelium stützt: Die Medien richten sich an eine Masse, während der christliche Gott sich an den einzelnen wendet. Van der Meiden versucht einen Mittelweg zwischen dem unkritischen und kritischen Gebrauch der Massenmedien. Er hält auch die Massenmedien christlich für berechtigt, wenn sie authentisch, freiheitlich und verantwortungsvoll sind. Medienmanipulation, Medienkampagnen entsprechen nicht diescm Standard. Mit dieser Einstellung würde man jedenfalls Gruppen errcichen, die nicht auf den Kirchenbesucher beschränkt sind.

Die vom Weltkirchenrat geforderten Kriterien beginnen mit dem Wer und Was der Kommunikation der Evangelien, wobei es am Anfang mehr auf den Inhalt als auf die Techniken ankommt. Aus einer solchen Grundeinstellung folgt dann u.a. die Forderung etwa der Zweiwegkommunikation. In mancher Hinsicht entsprechen diesc Kriterien dem rentralen Kanon westlicher Medienauffassung von Neutralität, und auch die Weltkirchenratskriterien versuchen - wic van der Meiden - einen Mittelweg zwischen unkritischem Gebrauch und der Ablehnung der Medien.

Manche aber halten diese beiden Versuche für unzureichend. Sie argumentieren, daß z.B. dic Reflexion über dic Evangelien verschiedenste theologische Schulen hervorgebracht hat und die Bibel für alles mögliche gebraucht wurde.

Positiv aber muß man vermerken, daß die Kirche doch einige Erfahrung hat, menschliches Leben und Gesellschaft an biblischen Kriterien zu messen und so auch in der Lage sein sollte, dies im Medienbereich zu tun. Dann aber sollte man ihre Möglichkeit, als Kirehe ein gutes Beispiel auch als Führerin der Kommunikation zu geben, nicht übersehen. Durch die Anwendung biblischer Kriterien in der eigenen Arbeit würde auch die Kommunikationskritik der Kirche glaubwürdiger. Ein rechter Mediengebrauch würde hier also - anders als bei Hamelink - der Kritik vorausgehen.

Das Problem, einen kritischen Begriffsrahmen zu entwickeln, liegt vor allem darin, Zustimmung zu einem solchen Rahmen zu finden. Kommunikation ist Teil von rund 50 verschiedenen Forschungs- 
disziplinen, die alle ihre eigenen Standpunkte haben, von der interpersonalen bis zur Massenkommunikation.

Es gibt keine allgemein angenommene Kommunikationstheorie. So wird nach Meinung von Soukup der philosophische Ansatz. 7.B. von der Wahl der Kommunikationssituation bestimmt. Die kritische Theorie ist hier von Bedeutung, weil einige ihrer Vertreter sie der Kirche verkaufen wollen. Wenn die Kirchen hier folgten, würden sie sich in einer mehr als fünfzigjährigen Diskussion über Ideologie und völkische Kultur auf eine bestimmte Seite stellen, was sicher von anderen kritisiert würde. Kritische Theorie wäre vielleicht für einige politische Missionarismen innerhalb der Kirche annehmbar, aber nicht für andere. Man könnte sie tatsächlich wohl kaum hinreichend begründen. Damit soll die kritische Theorie als Möglichkeit für den einzelnen nicht verworfen werden, aber man muß sich der Schwierigkeiten der Kirche für eine solche Annahme bewußt sein.

Aus verschiedenen Gründen hat eine personalistische Philosophie hier weniger Schwierigkeiten. Die Kirchen kennen sie deswegen schon besser, weil sie als kommunikativer Weg nicht nur von Martin Buber in „Ich und Du“ (1923) sondern auch durch Franz. Rosenzweig (,Stern der Erlösung“ 1921) und Gabriel Marcel („Journal métaphysique“ 1920ff.) eingeführt wurde. Deren Überlegungen zum Dialog haben die Kirchen so stark beeinflußt, daß dieser Dialog schon zu einem Klischee geworden ist. Außerdem ist die persona listische Philosophie im Gegensatz zur kritischen Theorie nicht einseitig einem Forschungsbegriff oder politischen Messianismus verbunden.

In Bubers Ich-Du-Beziehung ist keiner Subjekt des anderen, ist nicht nur Sender oder Empfänger. In der ausführlichen Diskussion dieser Buberschen Unterschreibung wird u.a. unterschieden zwischen Gemeinschaft und Gesellschaft. Hierher gehört u.a. auch die Diskussion zwischen Harvey Cox („The Secular City") und Martin Friedman ...

Personalistischer Einstellung ist die Achtung vor der menschlichen Person gemeinsam. In Bubers Philosophie wurde diese Achtung in einer dialogischen Beziehung gesehen. Aber hier geht es auch um die Erarbeitung eines personalistischen Kriteriums, nach dem menschliche Aktivität in einer integralen und adäquaten Betrachtung gesehen wird, wie sie auch "Gaudium et Spes" des Zweiten Vatikanums zugrundeliegt. Dies beinhaltet auch die gesellschaftliche Dimension der Person ebenso wie ihre Originalität.

Die Anwendung der personalistischen Kriterien auf Kommunikation hat u.a. zwei Folgerungen: 1. Wenn es die gesellschaftliche Dimension einschließt, anerkennt es auch implizit die Rolle der Kommunikation allgemein, aber 2. gewährt es auch einen Zugang zu der Diskussion über die Massenkommunikation, die im gesamten Kontext und nicht als einzelner äußerer Akt gesehen werden muß. Theologisch offenbart Jesus Christus, was mit integraler und angemessener Berücksichtigung der Person gemeint ist und biblisch belegt wird. Hier ergibt sich also auch ein Zusammenhang zwischen biblischen Richtlinien und dem kritischen Rahmenbegriff.

Das Problem heute ist oft, die Menschen überhaupt dazu zu bringen, über die Massenmedien nachzudenken; denn sie schwimmen offensichtlich darin wie der Fisch im Wasser, der auch über dieses Wasser nicht nachdenkt. Hier geht es um eine entsprechende Bewußtseinsbildung, aber auch um eine mehr politische Dimension des Personalismus, die Paolo Freire als das „Ansprechen des wahren Wortes“, als "die Welt nennen“" bezeichnet, was schnell zur Frage der Befreiung des Menschen führt. Der Wechsel von Buber zu Freire vom nicht direkten zum direkten Dialog ergibt eine politische Dimension. Hier zeigt sich also eine andere Möglichkeit, die Diskrepanz zwischen Kirche, Kommunikation und Kommunikationspraxis zu überwinden: die Annahme eines kritischen Begriffsrahmens, mit dem gegenwärtige Kommunikationssysteme geprüft und Ergebnisse für die Medienarbeit ausgewertet werden.

Zusammenfassend gibt es drei Folgerungen: 1. Es besteht offensichtlich eine Verbindung zwischen biblischen Richtlinien und der personalistischen Philosophie Bubers. 2. Die Art, wie diese Richtlinien und die personalistische Auffassung zusammenkommen, muß in Christus als Inspiration und Modell gesehen werden. 3. Eine entsprechende Bewußtseinsbildung über die Wirkweise der Medien ist notwendig.

\section{RESUME}

Le point de départ de ce document est le fait bien connu que l'utilisation des média par les Eglises va plus loin que leur attitude face au sujet. Après la reconnaissance du besoin d'avoir conscience de ce fait, le 
document résume deux possibilités pour développer cette conscience: l'examen de la communication propre des Eglises en considérant les directives de l'Evangile et l'articulation d'une construction conceptuelle et critique plus générale. Les deux possibilités ont leurs problèmes. Par exemple, dans le cas de la construction conceptuelle, les représentants des Eglises, du messianisme théorique et politique différent, trouveront difficilement un accord. Le document ne mentionne pas la théorie critique comme option individuelle, mais on considère qu'elle est invraisemblable pour l'Eglise. Les directives mentionnées ci-dessus de l'Evangile et, comme construction conceptuelle, la philosophie et théologie personaliste sont trop loin d’être des alternatives parfaites. Quelques pensées sont résumées pour les deux alternatives. Finalement, la nature complémentaire des directives de l'Evangile et de la philosophie personaliste est suggérée.

\section{RESUMEN}

El artîculo tiene su punto de partida en el hecho bien conocido que el uso que hacen las lglesias de los media va más allá que su propia opinión sobre este tema. Despues de haber reconocido la necesidad de estar conscientes de este hecho, el artículo intente resumir dos posibilidades para desarrollar esta consciencia. Por una parte la comunicación propia a la lglesia deberia ser invocada teniendo en cuenta los lineamientos evangélicos y por otra parte se deberîa articular un marco conceptual de trabajo, más general y crîtico. Ambos enfoques tienen sus problemas, los que son tratados en este artículo. Por ejemplo, en el caso de un marco conceptual de trabajo, la gente des Iglesia con diferentes concepto sobre la theorîa y la politica mesiánica, tendrán dificultades para llegar a un consenso. Aún si el artículo no toma una determinación sobre la crîtica teórica como una opción individual, si se considera quc no corresponde desde un punto de vista de Iglesia. Las dos alternativas ya mencionadas, lineamicntos evangélicos y como marco conceptual de trabajo una filosofîa-teologìa personalista, estan lejos de ser perfectas. En ambos casos algunos pensamientos son resumidos. Finalmente se sugiere la naturaleza complementaria de estas dos alternativas, directivas evangelicas y filosofia personalista. 